Dhani Setyawan

\title{
DECOMPOSING THE INFLUENCING FACTORS OF ENERGY INTENSITY IN THE PASSENGER TRANSPORTATION SECTOR IN INDONESLA
}

Indonesia's transport sector has experienced rapid growth that has caused excessive fossil fuel energy consumption. Over 2000 to 2016 total final energy consumption in Indonesia's transport sector has grown by 10\% per annum so that transport now provides a large and rapidly growing component of total energy use. This study analyzes the specific characteristics of energy intensity in the transportation sector in Indonesia from 2000 to 2016 by employing a multiplicative Log Mean Divisia Index-II. The passenger transport sector in Indonesia, including the four modes of road, rail, water and air is examined in this study. Overall, the decline in energy intensity in passenger transport is attributed to the intensity effect. In passenger transport, the improvement of intensity effect was found to have significantly reduced the overall aggregate energy intensity, while the change in structural effect was found to have a relatively small reduction in the aggregate energy intensity.

Keywords: energy efficiency, passenger transportation, energy intensity, Indonesia

\section{Introduction}

Indonesia's transportation energy consumption is rapidly increasing, primarily due to rising economic activity and population growth. As an emerging economy and the fourth most populous country in the world [1], Indonesia's economic growth has had around 6\% growth every year since 2010, leading to an increase in the mobility of the middle class [2]. Indonesia's transportation sector has gone through the rapid development, causing a significant use of fossil fuel energy consumption. This sector uses more than $60 \%$ of Indonesian's total oil use, approximately $70 \%$ of which is consumed in road transportation [2].

In the last decade, Indonesia had experienced several increases in fuel prices ${ }^{2}$ (see Table 1). Subsidies for fossil fuels were increasing as a portion of the national budget, although the recent price increase was the lowest in the world, particularly for a net importing country [3]. Starting from 2005, the Indonesian Government had cut subsidies for energy and increased fossil fuel prices more than threefold. The purpose of this energy price reform was not only to limit the difference between international and domestic prices but also to bring decrease the burden on the state budget; as the budget for fuel subsidies accounted a substantial percentage in the national state budget [4].

\footnotetext{
${ }^{1}$ Thus far, the energy prices including electricity, natural gas and fossil fuel have been fully regulated by the government. The Indonesian government oversees the price of fossil fuel products with adjusting periodically following a formula in which the international price plays an important variable.
}

Some studies [7-8] show that an increase in energy price can significantly improve energy efficiency. Therefore, the energy price instrument is one of the essential tools for energy reform and subsidies for energy is a key determinant of energy prices. The most common definition of an energy subsidy is a payment from government to consumer or producer in order to control energy prices [9-10]. In Indonesia, energy subsidies are mainly used by the government to control the energy price lower rather than the economic production cost.

Since the transportation sector in Indonesia is very complex and the statistical energy data in the transportation sector is limited, this study only investigates Indonesia's passenger transportation for a limited period. This study examines all the four modes of the transportation system in Indonesia: road, rail, water and air. Those modes of transport are used to measure the level of energy intensity in the passenger transport sector. This study is crucial for Indonesia's government in order to develop policies to improve energy efficiency, as well as to investigate the driving factors that affect the changes in transportation energy usage.

\section{Literature review}

The decomposition indices method has been extensively employed in measuring the driving factors behind the changes in energy used in transport. Authors of [11] investigated changes in the structure of passenger transport energy consumption in eight OECD countries from 1970 to 1987 by employing Laspeyres Divisia Indices. 
Table 1 Fossil fuel subsidy reforms since 2005

\begin{tabular}{lll}
\hline Year & Fuel Type & Fuel price policy reform \\
\hline 2005 & Diesel and gasoline & $\begin{array}{l}\text { Manufacturing industries are no longer able to get subsidized diesel. In March, the price } \\
\text { increased by } 29 \% \text { and further increased in October by } 114 \% .\end{array}$ \\
2006 & LPG & $\begin{array}{l}\text { LPG price increase targeted to manufacturing industries } \\
\text { In order to encourage LPG use, the government introduce the kerosene to LPG conversion } \\
\text { program }\end{array}$ \\
2007 & Kerosene and LPG & In January, Diesel and gasoline decreased by $7 \%$ and $11 \%$, respectively. \\
2009 & Diesel and gasoline & Both diesel and gasoline are increased by around $40 \%$ \\
2013 & Diesel and gasoline & Electricity base tariff increased by $15 \%$ \\
2014 & Diesel and gasoline & Both Diesel and gasoline are increased by $36 \%$ and $31 \%$, respectively \\
2015 & Diesel and gasoline & Gasoline subsidies are removed and diesel subsidies are reduced by Rp $1,000 /$ litre.
\end{tabular}

$\mathrm{Rp}=$ Rupiah, $\mathrm{Kg}$ = kilogram, $\mathrm{LPG}=$ liquefied petroleum gas.

Source: [5-6].

Their study observed that shifting to more energy intensive transport mode and increasing passenger-kilometres has become the main reason for the increase in energy use.

As the economic theory forecasts that a higher price will affect in decreasing consumption. Thus, an increase in fuel price is considered in this paper as a factor affecting the changes in energy intensity. In [12-13] is argued that reducing the energy price will decrease energy intensity and lead to an improvement in energy efficiency. Additionally, by employing firm level data, in [14] is demonstrated that a rise in different type of energy products ameliorate energy efficiency. Furthermore, a strong evidence of energy savings, resulting from a higher energy price in China's paper industry, is revealed in [15], as well. Increases in the energy price result in decreasing energy intensity by means of efficient usage and structural adjustment, [16-17].

Nevertheless, there are contrasting points of view regarding the influence of price on energy intensity. By employing provincial level data, in [17] is suggested that energy price had a lesser effect on energy efficiency. Further, authors of [18] investigated at China's provincial level and revealed that the role of energy price to energy intensity is weak compared to other factors.

Other research also reveals some drawbacks of high subsidies that lead to inefficiency and failure in providing an affordable energy price for the poor. In [19-21] is observed that the high subsidized energy prices are more benefitting the non-poor households rather than the poor. Further, author of [22] argued the needs of reducing the cross-subsidies of electricity rates in India that less are optimal for several consumer groups. With regard to the high subsidies of energy in Indonesia in the previous few decades, the influence of energy subsidy to the overall trend of energy intensity in the transport sector is essential as one of the factors that will be measured in this study.

Besides those studies, other researches also relate the drawbacks of transportation mobility to the environment. In [23] are investigated changes of the Green House Gases (GHG) level from the electric mobility implementation and found varies impact in different countries. Furthermore, the impact of the road traffic on the environment is observed in [24] and importance of information and education in reducing the negative impacts of transport is emphasized. Authors of [25] have focused on road freight transport and the GHG emissions and concluded that biofuels are more favourable compare to fossil fuels. Another study from [26] also investigated the advantages and disadvantages of electromobility in the freight transport and suggested the importance of transport policy implementation in EU countries.

\section{$3 \quad$ Methodology}

This study investigates the driving forces of and examines the transportation energy consumption trend for, Indonesia by applying the Log Mean Divisia Index (LMDI) method for period 2000 to 2016. The transportation energy consumption is classified as passenger transportation, covering the four modes: road, water, rail and air. To determine changes in energy intensity trends, the following approach is employed [27]:

$I_{t}=\frac{E_{t}}{Y_{t}}=\sum_{k=1}^{n} \frac{Y_{k t}}{Y_{t}} \frac{E_{k t}}{Y_{k t}}=\sum_{k=1}^{n} S_{k t} I_{k t}$,

where:

$I_{t}$ is the aggregate energy intensity at time t,

$E_{t}$ is the energy consumption in all transport sectors at time t,

$Y_{t}$ is the economic activity of all transport sectors at time t, $Y_{k t}$ is the economic activity in sector k at time t,

$E_{k t}$ is the energy consumption in sector k at time t,

$I_{k t}$ is the energy intensity of sector $\mathrm{k}$ at time $\mathrm{t}$,

$S_{k t}$ is the share of sector k in economic value of all transport sectors at time t.

Using multiplicative decomposition, the relation of the two time periods are described as below:

$D_{T o t, T}=\frac{T_{T}}{I_{0}}=D_{I n t, T} \times D_{S t r, T}$, 
Table 2 Variables in the transport sector

\begin{tabular}{clcc}
\hline Subsector & Mode of transport & Structural factors & Intensity factors \\
\hline \multirow{3}{*}{ Passenger } & Road & & \\
& Rail & Share of total passenger & knergy per passenger kilometre ${ }^{2}$ \\
& Water & kilometre & \\
& Air & & \\
\hline
\end{tabular}

where:

$D_{S t r, T}$ is the structural effect at time $\mathrm{T}$ (an index that determines the effect of the structural shift),

$D_{I n t, T}$ is the intensity effect at time $\mathrm{T}$ (an index that determines the changes in sectoral energy intensity effect), which are computed as:

$$
D_{S t r}=\exp \left\{\sum_{k=1}^{N} \frac{L \frac{E_{k, T} E_{k, O}}{E_{T} E_{O}}}{\sum_{k} L \frac{E_{k, T} E_{k, O}}{E_{T} E_{O}}} \ln \left(\frac{S_{k, T}}{S_{k, O}}\right)\right\},
$$

and

$$
D_{\text {Int }}=\exp \left\{\sum_{k=1}^{N} \frac{L \frac{E_{k, T} E_{k, O}}{E_{T} E_{O}}}{\sum_{k} L \frac{E_{k, T} E_{k, O}}{E_{T} E_{O}}} \ln \left(\frac{I_{k, T}}{I_{k, O}}\right)\right\} .
$$

Energy intensity for passenger transport was computed separately in this study, to compare the energy efficiency improvement in each type of transport mode. The structural and intensity effects are the two driving forces that are attributed for the changes in aggregate energy in transportation. The energy intensity effect is a ratio that relates to energy consumption and turnover, which represents the energy efficiency of transportation activity. This effect is predicted to decrease over time, owing to development of more energy efficient technologies. In addition, the structural effect captures the change of turnover for each transport mode. This effect measures changes of energy use in due to the changes in modes of transports share of the economy. All the things being equal, the changes in the level of transportation turnover modal shares directly affect the level of transportation energy consumption modal share.

\section{Data}

Due to the lack of energy statistical data in the transportation sector in Indonesia, this study only takes into account the four modes of transport: road, water, rail and air. The data for this study comes from a peer-reviewed database of transport data: The Transport Databank [28]. This data is a collaboration of the Asian Development Bank (ADB), the Clean Air Asia's Transport Research Laboratory, University of California Davis' Institute of Transportation Studies and the Partnership of Sustainable, Low Carbon Transport (SLoCaT). The collaboration published a database on transport with a focus on Asia and the Pacific.
The historical data was constructed from national surveys and international statistics [28]. Table 2 below describes the variables in the passenger transport sector in this study.

In terms of moving passengers, this study measured activity by the passenger-kilometre (PKM). The PKM measures efficiency of the passenger transport by calculating how much energy is needed to move one passenger per kilometre. The energy consumption for passenger transport is measured in Kilo Ton of Oil Equivalent (KTOE). Changes in energy consumption are decomposed in terms of the structural effect and intensity effect using the relative contribution of the passenger tasks. This study separates the analysis of passenger and freight sectors differently as the underlying economic factors shaping for both sectors differed [29].

\section{Analysis of energy consumption in the transportation sector}

As increasing energy consumption aligns with economic growth, which is defined as the GDP per capita [30], it is worth comparing the transport energy use and GDP. Figure 1 shows the increasing trend both in GDP and transport energy consumption in Indonesia from 2000 to 2016. Thus, in general, as the GDP and energy use increase, it can be assumed that it will be aligned with increasing mobility and improved standard of living. Turnover in the passenger transport is influenced by several factors, for instance, population growth, urbanization and changes in income, where these factors are expected to change the level of energy consumption in the transport sector [31-32].

While the value added data are available for total transport, the data for road passenger transport is not available separately. Given that this variable is important (each providing about half of energy use in transport by 2015) but also so distinctive, this study analyzes it separately, using dominators for the energy intensity measures (passenger kilometres), for the period 2000 to 2016.

\subsection{The passenger transport}

In passenger transport, the aggregate turnover and aggregate energy consumption have grown approximately four-fold from 2000 to 2016, generated substantially by an increase in the distance travelled per passenger [33]. The

${ }^{2}$ A passenger kilometre is defined as one passenger being moved one kilometre. 
Trends in Transportation Energy Consumption and GDP

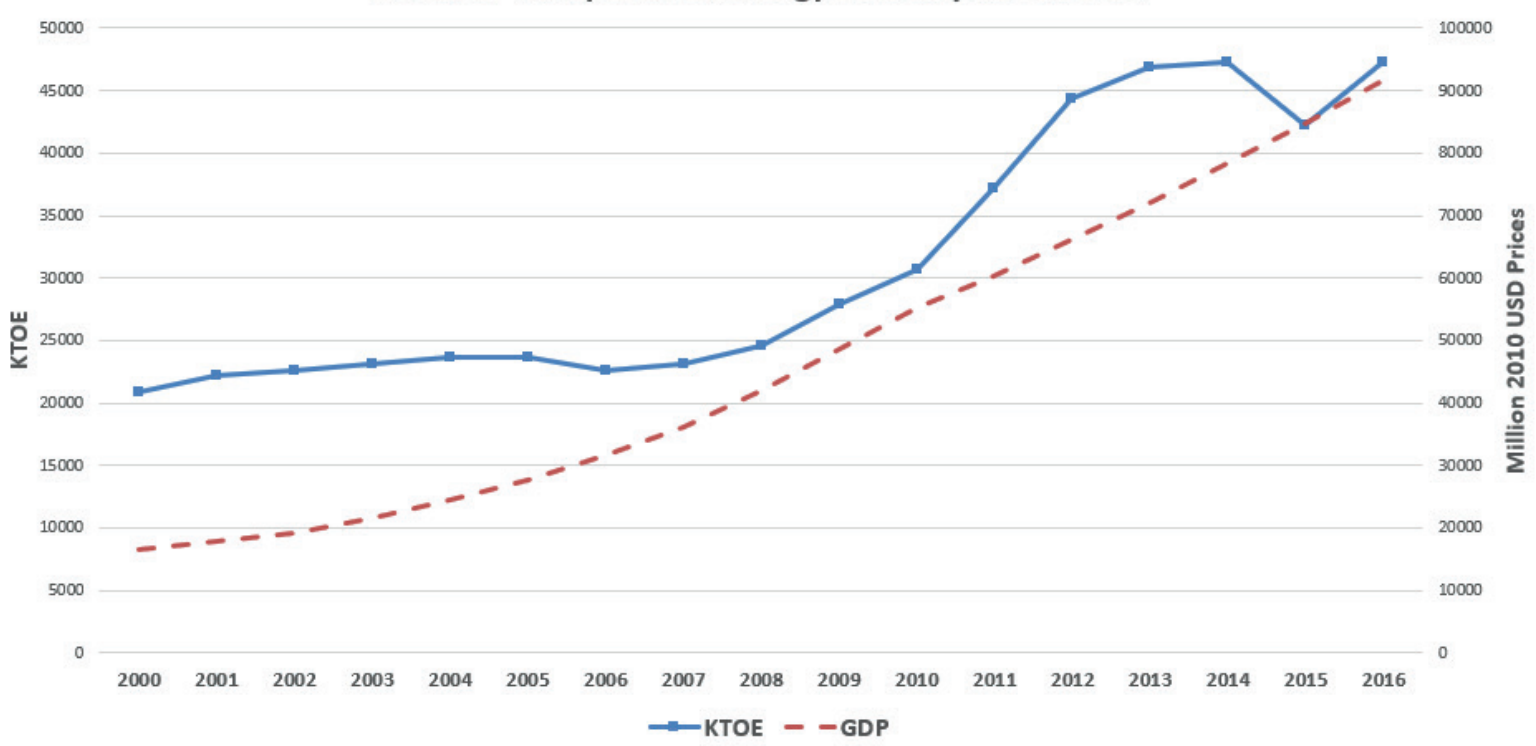

Figure 1 Trends in the transportation energy consumption and GDP

Table 3 Share and Growth of Turnover (Passenger Transport - PKM)

\begin{tabular}{|c|c|c|c|c|c|c|c|c|c|c|}
\hline \multirow{2}{*}{ Sectors } & \multicolumn{5}{|c|}{ Annual Growth Rate of Passenger Turnover (\%) } & \multicolumn{5}{|c|}{ Share of Total (\%) } \\
\hline & $00-05$ & $05-08$ & $08-14$ & $14-16$ & $00-16$ & 00 & 05 & 08 & 14 & 16 \\
\hline Road & 11.6 & 21.6 & 5.4 & 4.8 & 10.1 & 94.6 & 95.4 & 96.4 & 95.7 & 95.6 \\
\hline Rail & -5.7 & 7.7 & -0.3 & 1.1 & -0.4 & 2.7 & 1.2 & 0.8 & 0.6 & 0.5 \\
\hline Water & 0.5 & 8.3 & 8.1 & 5.8 & 5.4 & 0.5 & 0.3 & 0.2 & 0.2 & 0.3 \\
\hline Air & 19.5 & 13.1 & 11.2 & 5.4 & 13.3 & 2.2 & 3.2 & 2.6 & 3.5 & 3.6 \\
\hline Aggregate & 11.4 & 21.2 & 5.5 & 4.8 & 10.1 & & & & & \\
\hline
\end{tabular}

passenger transport turnover increased from 710 billion PKM in 2000 to 3,286 billion PKM in 2016, with an average annual growth rate of $10.1 \%$. For the same period, the total energy consumption in the passenger transport increased from 12,957 KTOE in 2000 to 54,384 KTOE in 2016 with an average annual growth rate of $9.4 \%$. It is apparent that the increasing energy consumption growth and its turnover tracked each other very closely, with average yearly growth rates of $9.38 \%$ and $10.05 \%$, respectively. This growth illustrates that Indonesia's transportation sector experienced an increasing energy usage and steady development, driven by many forces, including economic growth and improved standard of living.

The largest turnover share in the passenger transportation sector came from the road transport with approximately around $95.6 \%$ of the aggregate turnover in the passenger transportation sector in 2016 (see Table 3). Following the road transport, the air, rail and water transport accounted for around 3.6\%, $0.5 \%$, and $0.3 \%$, respectively. It is not surprising that the road transport has the largest share given the vast development of Indonesia's highway networks over the last decade.

The road transport has quite a steady turnover share from around $94.6 \%$ in 2000 to about $95.6 \%$ in 2016 . The turnover share of the rail and water modes decreased quite significantly during the study period from around $2.7 \%$ and
$0.5 \%$ in 2000 to $0.5 \%$ and $0.3 \%$ in 2016 , respectively. The turnover in the air transport increased from around $2.2 \%$ in 2000 to about $3.6 \%$ in 2016 . The change in the air travel activity suggests that travellers are increasingly choosing to fly rather than to use other modes of transport. Domestic aviation was the fastest growing mode of the passenger transport, increasing by around 19\% per year from 2000 to 2005 and approximately $13 \%$ annually from 2000 to 2016 . Activity in other modes of the passenger transport also expanded, except for the rail transport mode that had the lowest growth over the period. Indeed, the rail transport significantly slowed its growth during the study period.

For a closer look at the structural proportion of energy consumption in the passenger transport, Table 4 illustrates the energy consumption of passenger transportation from 2000 to 2016 . The road transport was the highest energyconsuming sector, responsible for around $91.8 \%$ of that consumed by the total passenger transport in 2000 but decreasing to around $88 \%$ in 2016 . The share of the water transport and railway energy consumption decreased from $0.9 \%$ in 2000 to $0.5 \%$ and $0.2 \%$ in 2016 , respectively, while the share of civil aviation almost doubled from approximately $6.4 \%$ in 2000 to $11.4 \%$ in 2016.

The primary reason for changes in the transport sector energy consumption and turnover is the shift in use of different modes of transport. This shift occurred as 
Table 4 Share and Growth of Energy Consumption

\begin{tabular}{|c|c|c|c|c|c|c|c|c|c|c|}
\hline \multirow{2}{*}{ Sectors } & \multicolumn{5}{|c|}{ Annual Growth Rate of Passenger Energy Consumption (\%) } & \multicolumn{5}{|c|}{ Share of Total (\%) } \\
\hline & 00-05 & $05-08$ & $08-14$ & $14-16$ & $00-16$ & 00 & 05 & 08 & 14 & 16 \\
\hline Road & 10.3 & 19.2 & 4.9 & 4.7 & 9.1 & 91.8 & 89.7 & 91.1 & 88.1 & 88.0 \\
\hline Rail & -6.3 & 7.0 & 0.0 & 2.4 & -0.5 & 0.9 & 0.4 & 0.3 & 0.2 & 0.2 \\
\hline Water & -0.9 & 8.4 & 8.3 & 9.3 & 5.4 & 0.9 & 0.5 & 0.4 & 0.5 & 0.5 \\
\hline Air & 19.5 & 13.3 & 11.1 & 5.4 & 13.3 & 6.4 & 9.4 & 8.2 & 11.2 & 11.4 \\
\hline Aggregate & 10.8 & 18.6 & 5.5 & 4.8 & 9.4 & & & & & \\
\hline
\end{tabular}

Table 5 Energy intensity in passenger transport sector

\begin{tabular}{|c|c|c|c|c|c|c|}
\hline \multirow[t]{2}{*}{ Sectors } & \multicolumn{5}{|c|}{$\begin{array}{c}\text { Passenger Energy Intensity } \\
\text { (KTOE/ Billion Passenger Kilometre) }\end{array}$} & \multirow{2}{*}{$\begin{array}{c}\text { Energy Intensity Changes (\%) } \\
00-16\end{array}$} \\
\hline & 00 & 05 & 08 & 14 & 16 & \\
\hline Road & 17.7 & 16.7 & 15.7 & 15.2 & 15.2 & -14.0 \\
\hline Rail & 6.0 & 5.9 & 5.7 & 5.8 & 6.0 & -1.0 \\
\hline Water & 31.9 & 29.6 & 29.7 & 30.0 & 31.9 & -0.2 \\
\hline Air & 52.9 & 52.9 & 53.1 & 52.9 & 52.9 & -0.1 \\
\hline Aggregate & 18.2 & 17.7 & 16.6 & 16.5 & 16.6 & -9.3 \\
\hline
\end{tabular}

changes from less intensive energy consumption mode, for instance, the railway transport, to more intensive energy consumption modes the road and air transport.

Table 5 shows the energy intensity of each transport mode in 2000, 2005, 2008, 2014 and 2016. From 2000 to 2016, the aggregate energy intensity in the passenger transport sector decreased by around $9.3 \%$. The declining trend in this period was mainly driven by the declining trend of energy intensity in the road transport for about 14\%, followed by the rail, water and air transport sector for approximately $1 \%, 0.2 \%$ and $0.1 \%$, respectively.

Overall, the energy intensity of the passenger transport sector declined steadily over the period from 2000 to 2016 . In Table 5 can be seen that the least efficient transport mode or the highest energy intensity in the passenger transport is civil aviation, followed by the water transport with road and rail transport in the third and fourth place. The aviation sector is the least efficient mode, as it requires around 53 KTOE per billion passenger kilometres, accounting to nearly three times more than that by the road transport and almost nine times with respect to the railway. The most efficient transport mode in passenger transport is railway, which requires only around six KTOE per billion passenger kilometres.

\section{Decomposition analysis}

The final energy use in the passenger transport sector rose during the study period. From 2000 to 2016, the energy intensity in the passenger transport declined from approximately $18.2 \mathrm{KTOE} /$ billion tonne PKM in 2000 to 16.5 KTOE/billion PKM in 2016 (decreasing around 9.3\%). By employing the LMDI method, this study estimates the driving forces of the passenger transport-related energy consumption in Indonesia, including the structural effect (DSTR) and intensity effect (DINT). As the energy source for the transportation sector mainly comes from oil and oil products, the decomposition analysis is divided into several sub-periods following the rising of the oil price in Indonesia. During the study period, the fuel price had been increased periodically. Diesel price was increased twofold in 2005, while in 2008 both diesel and petrol were raised $^{3}$ by one-third [4]. In 2013, the Indonesian government further increased diesel and petrol prices by $22 \%$ and $44 \%$, respectively. Further, in November 2014, petrol and diesel were again increased by $31 \%$ and $36 \%$, respectively.

Results of decomposition for the passenger transport in Indonesia from 2000 to 2016 are presented in graphical form in Figure 2.

The decomposition results in the passenger transport in Figure 2 show that the transportation energy intensity effect (DINT) significantly contributed directly to reduce the aggregate energy intensity (DTOT), while the role of the structure effect (DSTR) is found to be relatively small in most sub-periods. The energy intensity effect contributes strongly in decreasing the total energy intensity in the passenger transport. From 2000 to 2016, this effect induced a decrease in the passenger transport energy intensity for around $13 \%$, while the structural effect increased the energy intensity for only $4 \%$. The structural effect has had a negative effect on energy intensity in the passenger transport sector over this period. Overall, between 2000 to 2016, the aggregate energy intensity (DTOT) in the passenger transport decreased by around $9 \%$ as compared to its base level in 2000 .

\footnotetext{
${ }^{3}$ In 2005, premium gasoline has been raised from Rp 1800 to $\mathrm{Rp}$ 4500 /litre and kerosene from Rp 700 to Rp 2000 /litre. Further, in 2008, premium gasoline has been raised from $\mathrm{Rp} 4500$ to $\mathrm{Rp} 6000$ /itre and kerosene from Rp 2000 to 2500 /litre.
} 


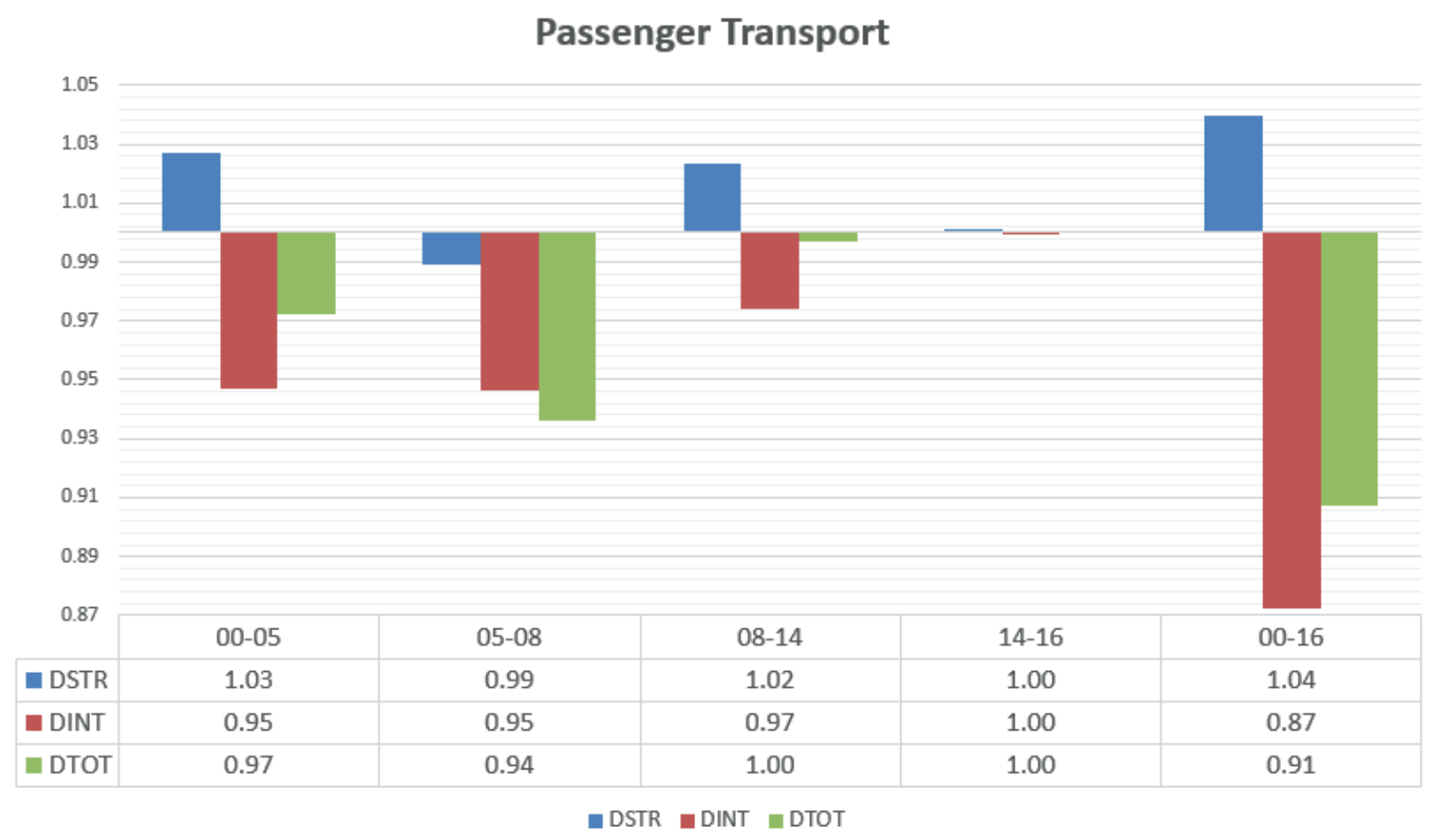

Figure 2 Decomposition result of the passenger transport

From 2005 to 2008, the structural effect contributed an $1 \%$ reduction in the energy intensity, while the intensity effect decreased it by around 5\%. Overall, the aggregate energy intensity in the passenger transport decreased by around 6\% during this period. In the period of 2008 to 2014 , the aggregate energy intensity in the passenger transport was stable, due to the increase in the structural effect that was offset by the intensity effect.

The graph reveals that the energy efficiency in the passenger transport improved over the period from 2000 to 2016. This means that improving the transport intensity effect can significantly influence energy savings. This effect may relate to policy measures that have been enacted in Indonesia such as developing new green vehicle technology, improvement in fuel quality, advances in the transportation system and promoting energy alternatives, while, on the other hand, the increases in the structural effect potentially due to modal shifting, from less energy intensive mode, like rail transport, to more energy intensive modes such as the air and road transport. As noted earlier, the road transport sector has been a prominent transportation mode.

\section{Benchmarking Indonesia to other ASEAN countries}

This study provides an analysis of Indonesia's energy use compared to other selected ASEAN countries from 2000 to 2016. Due to a limit in the available data, in this study, the group of six ASEAN countries includes Indonesia, Malaysia, the Philippines, Thailand, Cambodia and Myanmar.

Figure 3 illustrates the passenger turnover share for the six selected ASEAN countries. The road transport has the largest share in the passenger transportation over the study period in all of the six selected ASEAN countries. From 2000 to 2016 this mode of transport contributes for more than $70 \%$ of the share for Malaysia, Thailand, the Philippines, Myanmar and Cambodia, where in Indonesia this mode contributed for more than $90 \%$. The second highest turnover contributor came from the air transport. In Cambodia, air transport almost doubled from $14.7 \%$ in 2000 to around $28.6 \%$ in 2016 , where the increase of aviation was followed with a decrease of the road transport. Another significant increase in the air transport can also be seen in Malaysia, where this sector contributed for around $26.3 \%$ in 2016 . The rail transport has quite a significant share in Myanmar for around 16.5\% in 2000 but fell to around $3.4 \%$ in 2016 . The water transport in the total turnover was found the lowest in all of the six ASEAN countries for less than 1\%, although in Cambodia it increased to around $4.4 \%$ in 2016.

Similarly, to the share of turnover, the energy consumption in the road transport mode also played a key role in the overall energy consumption in the passenger transport from 2000 to 2016 (Figure 4).

This mode of transport consumed more than $70 \%$ in all the six ASEAN countries, except Cambodia, where its energy consumption share decreased for almost a half from $63.9 \%$ in 2000 to $35.9 \%$ in 2016 . The share of energy consumption in air transport increased quite significantly in Malaysia, Thailand, Philippines, Cambodia and Indonesia which increased from 27.4\%, $20.3 \%, 15.1 \%, 36.1 \%, 6.4 \%$ to around $35.7 \%, 28.7 \%, 30.6 \%$, $58.4 \%, 11.4 \%$, respectively. Similar to the share of turnover, the share of energy consumption in railways and waterways were found to be insignificant in all of 


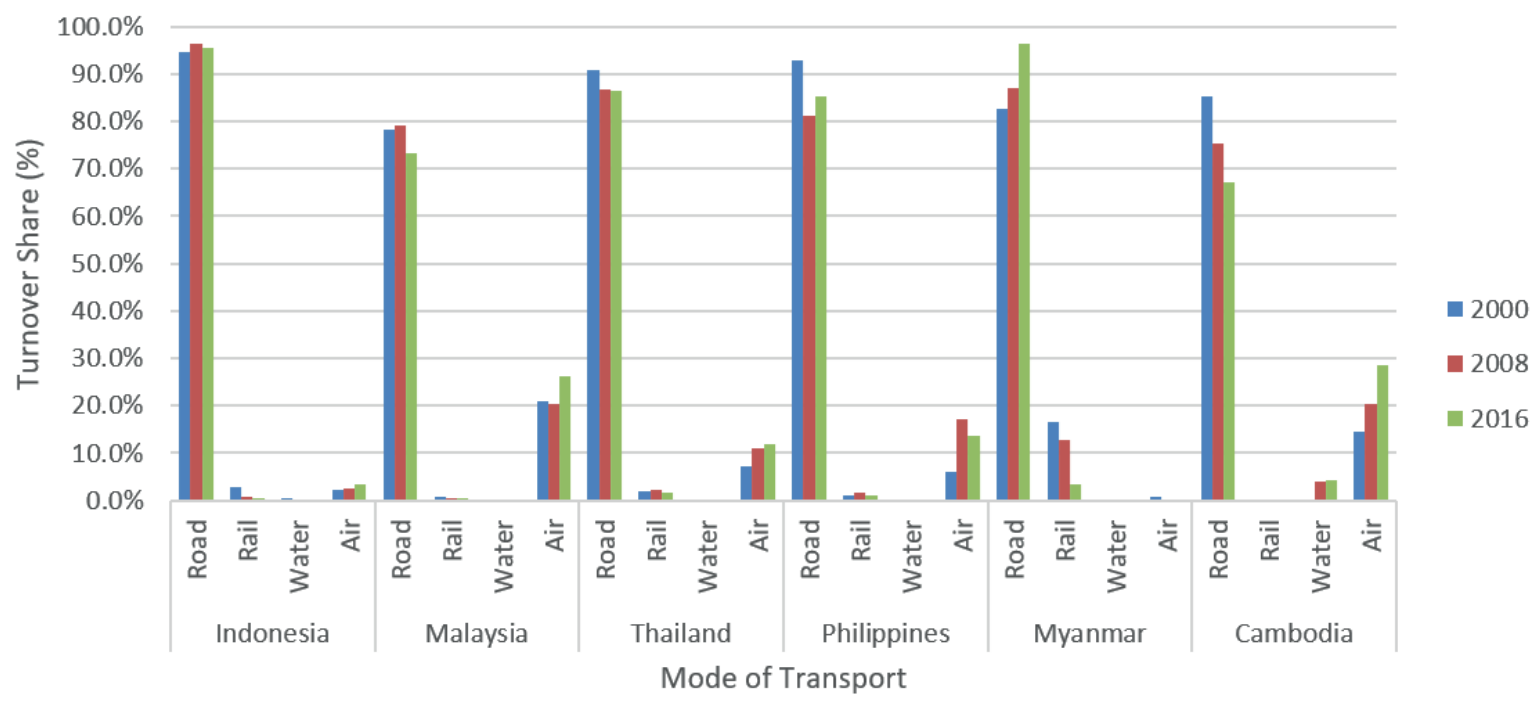

Figure 3 The passenger turnover share in ASEAN countries

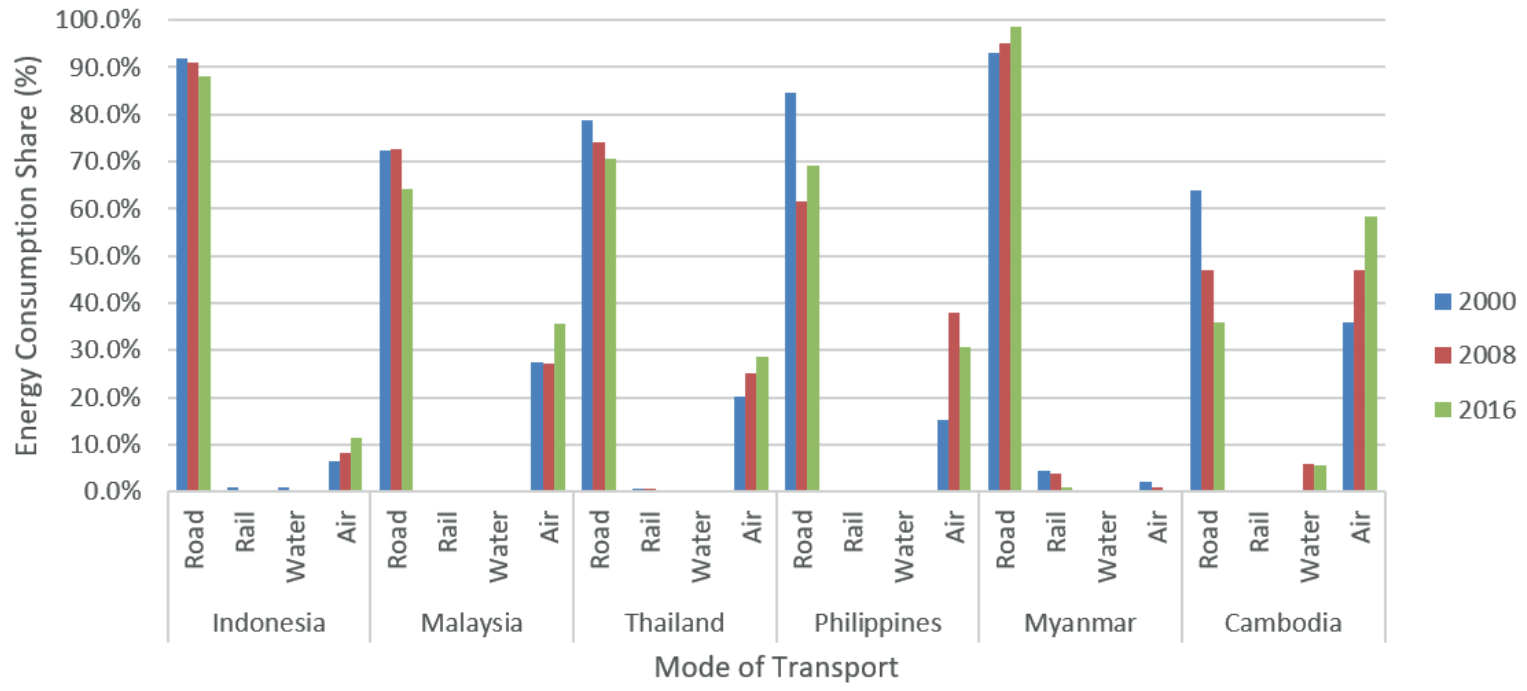

Figure 4 The passenger energy consumption share in ASEAN countries

the six ASEAN countries, which only covered less than $6 \%$ during the study period.

\section{Conclusions}

Regarding the turnover and energy use, the passenger transport in Indonesia experienced a substantial growth. The main factors affecting this trend were changes in the energy intensity, transport choices and turnover growth. For the passenger transport, the highest energy consuming mode and the major transport mode was the road transport. In spite of being a country with many archipelagos, the road transport contributed the largest turnover in passenger transport, whereas air, waterways and rail transport did not play a significant role in the passenger transportation in Indonesia. Over the study period from 2000 to 2016, the road transport accounted for the largest share, with more than $90 \%$ of the share in terms of passenger-kilometres travelled.

In the passenger transport, the structural effect (DSTR) had an increasing impact on the aggregate energy intensity in most years, although its magnitude was insignificant compared to the decreasing intensity effect. The increasing structural effect was associated with the modal shifting, from the less intensive energy modes, like railway, to more energy consumption modes, like road and aviation. In the passenger transport (see Table 3), the share of railways to total turnover dropped from $2.7 \%$ in 2000 to $0.5 \%$ in 2016 ; the air transport increased from $2.2 \%$ in 2000 to $3.6 \%$ in 2016; while the road transport increased only slightly by around 1\% in 2016 compared to the base year. Based on [33], the increasing demand of the air transport services in Indonesia recently has been encouraged by the substantial development of airways transport infrastructure, specifically airports and the growing of the low-cost airlines. Between 
2015 and 2016, the total number of airline passengers grew $10.5 \%$, to 95.2 million [33]. In line with the increasing turnover share in the aviation, the ratio of the air transport energy consumption to other modes also increased from around $6.4 \%$ in 2000 to approximately $11.4 \%$ in 2016 . Moreover, the energy consumption in the road transport decreased from $91.8 \%$ in 2000 to $88 \%$ in 2016 ; while the rail and water transport also had a slight decrease in energy consumption (see Table 4). The road transport has been the prominent transportation mode, which explains more than $90 \%$ of the total turnover and total energy consumption during the study period.

Over the period 2000 to 2016, the energy intensity of the passenger transport sector declined steadily. In the passenger transport, the decreasing aggregate energy intensity was attributable to the intensity effect that lowered the overall energy intensity in the passenger transport to around 9\% from 2000 to 2016. Further, the findings also indicate that the transportation energy intensity effect had a greater contribution in reducing overall energy intensity in the passenger transport; while the role of the structural effect increased the aggregate energy intensity. The reduction of the intensity effect can be associated with better and more effective policy measures, for instance encouraging the use of cleaner fuels, upgrading the traffic equipment and supporting development of the new technology. In addition, since the fuel price reform, Indonesia's energy prices have increased substantially, although it is lower than international fuel prices. Therefore, energy price changes potentially have had a small impact on the overall energy intensity changes in the transport sector.

\section{$9 \quad$ Policy implications}

Several features of Indonesia's transport system are distinctive in an international context. Almost all the passenger kilometres are travelled on roads (95.6\% in 2016), with virtually no rail $(0.5 \%)$ or water $(0.3 \%)$ passenger travel, but with a small but rising share of air travel (3.6\% in 2016). A good transportation system is one of the main components for strong economic growth [34]. However, energy consumption in this sector has grown continuously over the last decade and will potentially continue to increase in the future. Attempts to reduce the energy use in the transportation sector require significant attention, where the clear and coherent government policy needs to be established to conduct a suitable energy policy in this sector. Therefore, the findings in this study are aimed to establish a scientific evidence for developing a policy on energy efficiency measures in the transportation sector.

The structural effect of the passenger transport indicated a negative influence (that is, increasing) aggregate energy intensity over the period of the study. This seemingly indicates contradictory efforts in reducing overall energy intensity. Based on the observation of energy usage performance across the transportation modes in the study period, the breakdown of the road and air transport turnover for passenger has increased substantially, employing more energy per unit of turnover compared to other modes of transport. Therefore, to lower the level of energy use in the transport sector, one of the key policy measures required is to promote different modes of transport besides the road and air transport, such as railways, waterways transport and other modes of transport that consume less energy.

The road transportation system is a crucial sector that not only moves people and goods, but is also essential for industry and local trade. Therefore, the key strategy to further reduce the energy intensity growth in the transport sector is to lower the growth of energy consumption. Enacting green energy policies, such as shifting to cleaner energy fuels [35] and encouraging the use of public transport [36], including the rail and water transportation would help to reach this goal. Regulatory measures, including vehicle efficiency and occupancy standards [37] are needed to reduce the energy intensity in the transport sector. Moreover, fiscal measures, such as providing tax incentives and subsidies for development of the public transportation [36], cleaner fuels or development of green technology could be considered as an effective way to encourage awareness of the people to use energy more efficiently that leads towards a modal shifting to more energy efficient transport modes.

Overall, Indonesia's transport structure needs to be focused on the waterway and railway transports that have lower energy use and greater transport capacity. The Indonesian Government needs to enact various policy measures to expand investment in the waterways and railways. Improving development of the inland waterways and railways network can be done gradually by providing more effort in optimizing networks across different transport modes and enhancing the road infrastructure to make all the other transport modes closely connected [38]. These efforts are expected to create an efficient transport system, where railways and waterways become more dominant in the Indonesia's transport system.

\section{References}

[1] WorldBank 2014. Indonesia Economic Quarterly. Jakarta: World Bank Group, 2014.

[2] DEENDARLIANTO, WIDYAPARAGA, A., SOPHA, B. M., BUDIMAN, A., MUTHOHAR, I., SETIAWAN, I. C., LINDASISTA, A., SOEMARDJITO, J., OKA, K. Scenarios analysis of energy mix for road transportation sector in Indonesia. Renewable and Sustainable Energy Reviews [online]. 2017, 70, p. 13-23. ISSN 1364-0321. Available from: https://doi.org/10.1016/j.rser.2016.11.206 
[3] IEA 2015, Southeast Asia Energy Outlook 2015, Directorate of Global Energy Economics, International Energy Agency, France.

[4] HOWES, S., DAVIES, R. Survey of recent development. Bulletin of Indonesian Economic Studies [online]. 2014, 50(2), p. 157-183. ISSN 0007-4918, eISSN 1472-7234. Available from: https://doi.org/10.1080/00074918.2015.1016565

[5] ADB 2015, Fossil fueal subsidies in Indonesia, trends, impacts and reforms. Asian Development Bank, Manila, Philippines: Asian Development Bank, 2015.

[6] BEATON, C., LONTOH, L. Lessons learned from Indonesia's attempts to reform fossil-fuel subsidies [online]. Geneva, Switzerland: International Institute for Sustanaible Development, 2010. Available from: https://www.iisd.org/pdf/2010/ lessons_indonesia_fossil_fuel_reform.pdf

[7] CHEN, K.-H., YANG, H.-Y., LEE, J.-M., CHI, C.-F. The impact of energy prices on energy consumption and energy efficiency: evidence from Taiwan. Energy Efficiency [online]. 2016, 9(6), p. 1329-1349. ISSN 1570-646X, eISSN 1570-6478. Available from: https://doi.org/10.1007/s12053-016-9426-y

[8] HE, L., DING, Z,. YIN, F., WU, M. The impact of relative energy prices on industrial energy consumption in China: a consideration of inflation costs. SpringerPlus [online]. 2016, 5(1), p. 1-21. eISSN 2193-1801. Available from: https://doi.org/10.1186/s40064-016-2661

[9] IEA 1999. World energy outlook insights, looking at energy subsidies: getting the prices right. Paris: International Energy Agency (IEA).

[10] OECD 1998. Improving the environment by reducing subsidies. Paris: Organization for Economic Development and Cooperation, 1998.

[11] SCHIPPER, L., STEINER, R., DUERR, P., AN, F., STROM, S. Energy use in passenger transport in OECD countries: changes since 1970. Transportation: Planning - Policy - Research - Practice [online]. 1992, 19(1), p. 25-42. ISSN 0049-4488, eISSN 1572-9435. Available from: https://doi.org/10.1007/BF01130772

[12] KEPPLER, J., BIROL, F. Prices, technology development and the rebound effect. IDEAS Working Paper Series from RePEc, 2000.

[13] HANG, L., TU, M. The impacts of energy prices on energy intensity: evidence from China. Energy Policy [online]. 2007, 35(5), p. 2978-2988. ISSN 0301-4215. Available from: https://doi.org/10.1016/j.enpol.2006.10.022

[14] FISHER-VANDEN, K., JEFFERSON, G. H., LIU, H., TAO, Q. What is driving China's decline in energy intensity? Resource and Energy Economics [online]. 2004, 26(1), p. 77-97. ISSN 0928-7655, eISSN 1873-0221. Available from: https://doi.org/10.1016/j.reseneeco.2003.07.002

[15] LIN, B., MOUBARAK, M. Estimation of energy saving potential in China's paper industry. Energy [online]. 2014, 65, p. 182-189. ISSN 0360-5442, eISSN 1873-6785. Available from: https://doi.org/10.1016/j.energy.2013.12.014

[16] FARAJZADEH, Z., NEMATOLLAHI, M. A. Energy intensity and its components in Iran: determinants and trends. Energy Economics [online]. 2018, 73, p. 161-177. ISSN 0140-9883, eISSN 1873-6181. Available from: https://doi.org/10.1016/j. eneco.2018.05.021

[17] SONG, F., ZHENG, X. What drives the change in China's energy intensity: combining decomposition analysis and econometric analysis at the provincial level. Energy Policy [online]. 2012, 51, p. 445-453. ISSN 0301-4215. Available from: https://doi.org/10.1016/j.enpol.2012.08.044

[18] YANG, G., LI, W., WANG, J., ZHANG, D. A comparative study on the influential factors of China's provincial energy intensity. Energy Policy [online]. 2016, 88, p. 74-85. ISSN 0301-4215. Available from: https://doi.org/10.1016/ j.enpol.2015.10.011

[19] DUBE, I. Impact of energy subsidies on energy consumption and supply in Zimbabwe. Do the urban poor really benefit? Energy Policy [online]. 2003, 31(15), p. 1635-1645. ISSN 0301-4215. Available from: https://doi.org/10.1016/S03014215(02)00229-X

[20] GANGOPADHYAY, S., RAMASWAMI, B., WADHWA, W. Reducing subsidies on household fuels in India: how will it affect the poor? Energy Policy [online]. 2005, 33(18), p. 2326-2336. ISSN 0301-4215. Available from: https://doi.org/10.1016/ j.enpol.2004.04.024

[21] KEBEDE, B. Energy subsidies and costs in urban Ethiopia: the cases of kerosene and electricity. Renewable Energy [online]. 2006, 31(13), p. 2140-2151. ISSN 0960-1481, eISSN 1879-0682. Available from: https://doi.org/10.1016/ j.renene.2005.10.005

[22] CHATTOPADHYAY, P. Cross-subsidy in electricity tariffs: evidence from India. Energy Policy [online]. 2004, 32(5), p. 673-684. ISSN 0301-4215. Available from: https://doi.org/10.1016/S0301-4215(02)00332-4

[23] SKRUCANY, T., KENDRA, M., STOPKA, O., MILOJEVIC, S., FIGLUS, T., CSISZAR, C. (2019) Impact of the electric mobility implementation on the greenhouse gases production in central european countries. Sustainability [online]. 2019, 11(18), 4948. eISSN 2071-1050. Available from: https://doi.org/10.3390/su11184948

[24] GOGOLA, M., VETERNIK, M. The analysis of the environmental impact of road traffic in city of Martin. Logi - Scientific Journal on Transport and Logistics. 2016, 7(1), p. 49-60. ISSN 1804-3216. 
[25] LIZBETIN, J., HLATKA, M., BARTUSKA, L. Issues concerning declared energy consumption and greenhouse gas emissions of FAME biofuels. Sustainability [online]. 2018, 10(9), 3025. eISSN 2071-1050. Available from: https://doi.org/10.3390/su10093025

[26] CEMPIREK, V., RYBICKA, I., LJUBAJ, I. (2019). Development of electromobility in terms of freight transport. LOGI - Scientific Journal on Transport and Logistics [online]. 2019, 10(2), p. 23-32. ISSN 1804-3216. Available from: https://doi.org/10.2478/logi-2019-0012

[27] ANG, B. W. LMDI decomposition approach: a guide for implementation. Energy Policy [online]. 2015, 86, p. $233-238$. ISSN 0301-4215. Available from: https://doi.org/10.1016/j.enpol.2015.07.007

[28] ZHANG, X., EMMERSON, P. Transport databank. Clean Air Asia, 2016.

[29] LIPSCY, P. Y., SCHIPPER, L. Energy efficiency in the Japanese transport sector. Energy Policy [online]. 2013, 56, p. 248-258. ISSN 0301-4215. Available from: https://doi.org/10.1016/j.enpol.2012.12.045

[30] MASIH, A. M. M., MASIH, R. Energy consumption, real income and temporal causality: results from a multi-country study based on cointegration and error-correction modelling techniques. Energy Economics [online]. 1996, 18(3), p. 165-183. ISSN 0140-9883, eISSN 1873-6181. Available from: https://doi.org/10.1016/0140-9883(96)00009-6

[31] CHAI, J., LU, Q.-Y., WANG, S.-Y., LAI, K. K. Analysis of road transportation energy consumption demand in China. Transportation Research Part D Transport and Environment [online]. 2016, 48, p. 112-124. ISSN 1361-9209, eISSN 1879-2340. Available from: https://doi.org/10.1016/j.trd.2016.08.009

[32] TIWARI, P., GULATI, M. An analysis of trends in passenger and freight transport energy consumption in India. Research in Transportation Economics [online]. 2013, 38(1), p. 84-90. ISSN 0739-8859. Available from: https://doi.org/10.1016/ j.retrec.2012.05.003

[33] IEA 2017. Energy Efficiency 201\%. International Energy Agency, 2017.

[34] PRADHAN, R. P., BAGCHI, T. P. Effect of transportation infrastructure on economic growth in India: The VECM approach. Research in Transportation Economics [online], 2013, 38(1), p. 139-148. ISSN 0739-8859. Available from: https://doi.org/10.1016/j.retrec.2012.05.008

[35] SCHIPPER, L., NG, W. Rapid motorization in China: environmental and social challenges. ADB-JBIC-World Bank East Asia and Pacific Infrastructure Flagship Study, 2004.

[36] ADB 2006. Energy efficiency and climate change considerations for on-road transport in Asia. Philippines: Asian Development Bank (ADB), 2006.

[37] AN, F., SAUER, A. Comparison of passenger vehicle fuel economy and GHG emission standards around the world [online]. Arlington, VA: Pew Center on Global Climate Change, 2004. Available from: https://www.c2es.org/site/assets/ uploads/2004/12/comparison-passenger-vehicle-fuel-economy-ghg-emission-standards-around-world.pdf

[38] WANG, Y., LI, K. - P., XU, X. Transport energy consumption and saving in China. Renewable and Sustainable Energy Reviews [online]. 2014, 29, p. 641-655. ISSN 1364-0321. Available from: https://doi.org/10.1016/j.rser.2013.08.104 